\title{
GARDEN PROFILE The Royal Botanic Garden Edinburgh at 350
}

\section{David Knott ${ }^{1}$}

\section{Abstract}

The Royal Botanic Garden Edinburgh (RBGE) was founded in 1670 and celebrated its 350th anniversary in 2020. Located in Edinburgh, Scotland, the institute has occupied four different sites in that time and has been at the current site in the Inverleith area of the city since 1823. Three other gardens in Scotland are also part of RBGE: Dawyck in the Scottish Borders, Benmore in Argyll and Logan in Dumfries \& Galloway. A total of 13,598 species from 2,607 genera representing 322 families are cultivated in these four gardens, and this article describes some of these collections. It also describes the issues facing the Garden today in common with many large botanic gardens: those of plant health, implementing environmentally sustainable working practices, and managing collections in the face of a changing climate and growing visitor numbers. The Garden is also looking forward to an exciting future, with ambitious plans for new buildings and the refurbishment of historical structures to not only improve plant cultivation facilities, but also increase visitor engagement and education about the value of plants for a healthy future.

\section{A brief history of RBGE}

The Royal Botanic Garden Edinburgh (RBGE) was founded just over 350 years ago in 1670 , by two doctors - Sir Robert Sibbald (1641-1722) (Fig. 1) and Andrew Balfour (1630-1694) - with its primary purpose being to teach students of botany about plants and their identification and to train apothecaries in plant-based materia medica - the plants used in making medicines. However, no garden or gardener can resist acquiring and growing new plants, and with the appointment of James Sutherland to curate the plant collection it quickly expanded, as evidenced by the catalogue of plants he published in 1683 (Sutherland, 1683). There it is recorded that over 2,000 plants were cultivated. Within five years more space was required, and in 1675 the garden was moved to the grounds of Trinity Hospital, which is now occupied by Platform 11 of Waverley Station.

The appointment of John Hope as the fourth Regius Keeper in 1761 heralded a period of rapid change, and in 1763 the garden moved to a 5 acre ( $2 \mathrm{ha}$ ) site on Leith Walk. In this location, adjacent to the main thoroughfare between the centre of Edinburgh and the port of Leith, there was a glasshouse complex with ponds and fields of medicinal plants. John Williamson was in charge and referred to as the Principal Gardener. The variety of plants cultivated on the new site was down to the skill and diligence of Williamson. He also conducted the day-to-day activities and monitored the experiments set up by Hope. The importance of his activities and expertise is acknowledged by Hope on a memorial plaque dedicated

\footnotetext{
'David Knott is Curator of Living Collections at the Royal Botanic Garden Edinburgh. Address: 20A Inverleith Row, Edinburgh, EH3 5LR, UK. 


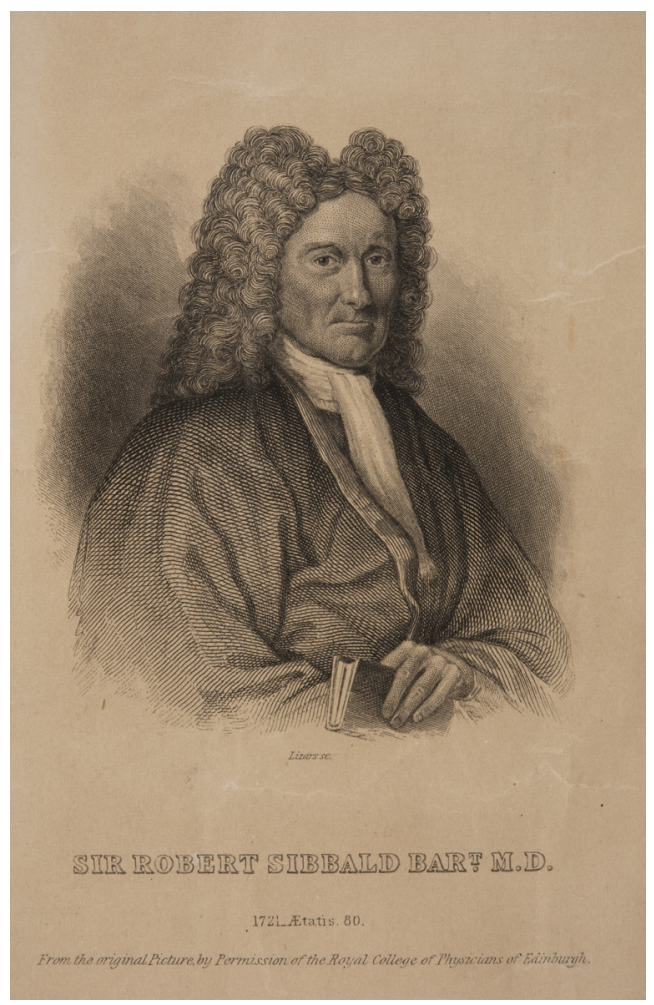

Fig. 1 Portrait of Sir Robert Sibbald. Credit: RBGE Library and Archives.

to him. The plaque was installed above the entrance door to the garden after his death, which occurred in 1780 as a result of pursuing smugglers in his second job as customs officer (Fletcher \& Brown, 1970). It should be noted that Agnes Williamson, John's daughter, did some of the teaching drawings of plant growth and experiments which Hope used in his classes (Noltie, 2011).

The garden quickly outgrew the Leith Walk site and moved to its current location at Inverleith between 1820 and 1823. The move was masterminded by William McNab, Curator 1810-1838, using his innovative tree planting machine. Many large trees were moved successfully from the Leith Walk garden to the new site at Inverleith. After the move there was a period of rapid development - including the construction of RBGE's oldest glasshouse, the Tropical Palmhouse, completed in 1834. One of the most recognisable buildings in the garden today is the iconic Temperate Palmhouse which was completed in 1858 and is still the tallest glasshouse of its kind in the UK (Fig. 2).

The 1960s saw another period of rapid development with the construction of the new Herbarium building and the Front Range Public Display Glasshouses (Fig. 3), which were completed in 1967. These innovative glasshouses maximise the growing space available inside because all the structural supports are external.

\section{Mission}

Today RBGE's mission is 'to explore, conserve and explain the world of plants for a better future.' In an era when the impacts of climate change and significant biodiversity loss are increasing and well recorded, this focus on the role of plants for a healthy future is ever more important (Antonelli et al., 2020). The resources of dried plant specimens in the Herbarium, the literature and art stored in the Library and Archives, and the plants cultivated in the Living Collection underpin the work of the Garden, and without them the research outputs of the institute would not be possible.

\section{The Living Collection}

Today the Living Collection is cultivated across four gardens in Scotland acquired over the last 100 years, each with its own climatic conditions and all located within $150 \mathrm{~km}$ of Edinburgh. The Collection also includes the plants conserved by the International Conifer Conservation Programme (ICCP). These are plants which have been wild collected and grown by ICCP and RBGE staff. When they reach a suitable size they are planted in 'safe 


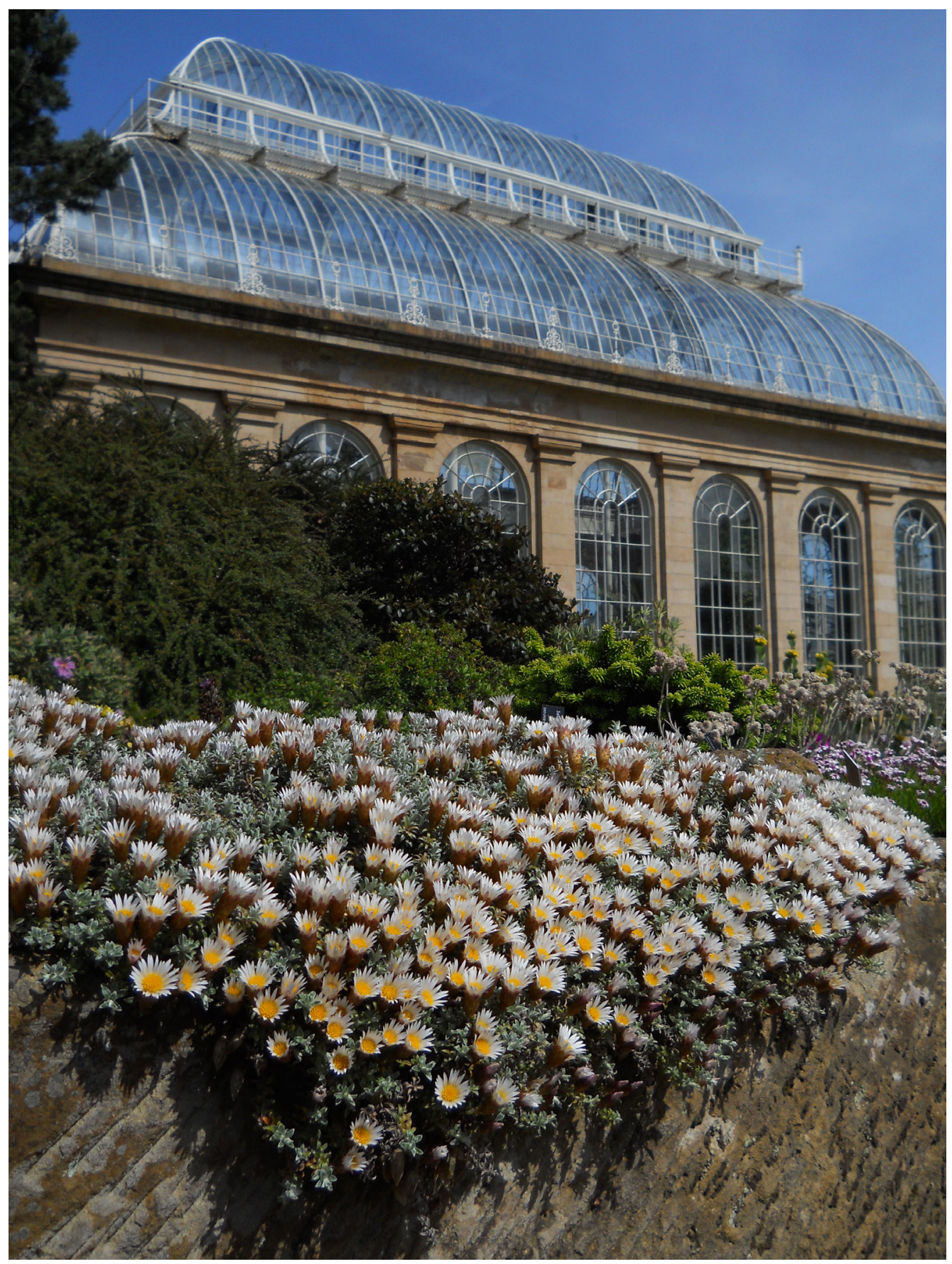

Fig. 2 The Temperate Palmhouse was completed in 1858 and is one of RBGE's iconic buildings. Photo: David Knott.

sites'. These safe sites are documented in the RBGE plant records database as part of the long-term monitoring and conservation of the species involved.
Edinburgh is the driest garden with an average annual rainfall of $750 \mathrm{~mm}$, although this is increasing. Benmore in Argyll is the wettest with $3,000 \mathrm{~mm}$ rainfall, and currently 


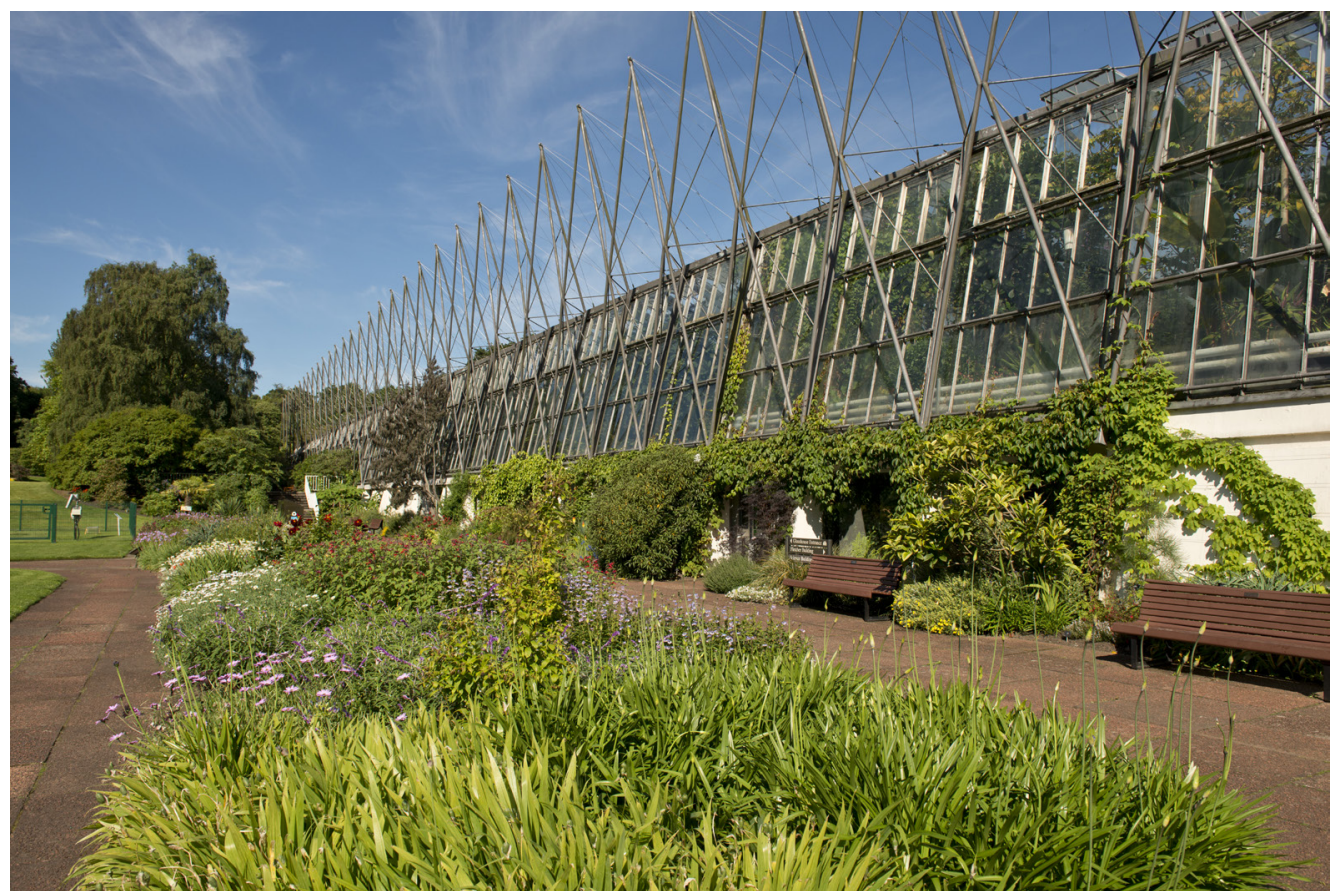

Fig. 3 The Front Range was completed in 1967 and is Grade A listed. Photo: Lynsey Wilson.

holds the record for being the warmest garden at $30{ }^{\circ} \mathrm{C}$ (Fig. 4). Logan in Dumfries \& Galloway is the mildest, with air frosts in recent years being very uncommon and rainfall in the region of $1,200 \mathrm{~mm}$ (Fig. 5). And Dawyck in the Scottish Borders is the coldest, with an absolute minimum of $-20^{\circ} \mathrm{C}$ and rainfall of around 1,200 $\mathrm{mm}$ (Fig. 6).

The priorities for the horticultural team are the curation of the internationally important Living Collection, the maintenance and development of the four garden landscapes, and the conservation of plant species including the restoration of Scottish native plant species. Training and capacity building students and interns from the UK and other countries and environmental sustainability activities form another important part of the horticultural staff's working days.

The Collection Policy for the Living Collection ensures that there is an awareness of, and compliance with, the current national and international protocols (Rae et al., 2006). This Policy also includes the landscape design, acquisition and transfer criteria for each of the four gardens and lists the priorities for each collection. In brief, the Collection Policy ensures that the right plant is in the right place at the right time for the right reason and purpose.

The Living Collection across all four gardens currently comprises 13,598 species from 2,607 genera representing 322 families, with approximately 77,000 plants being cultivated in the gardens, and more under propagation in the nurseries. Of these, 60 per cent are of wild origin and 26 per cent have been verified (data from the RBGE plant records database IrisBG, 2021). Plants from over 156 countries are cultivated across all 4 gardens. These include 9 UK Plant Heritage collections and 244 Champion Trees as designated by the Tree Register of the British Isles (Tree Register, 2021). 


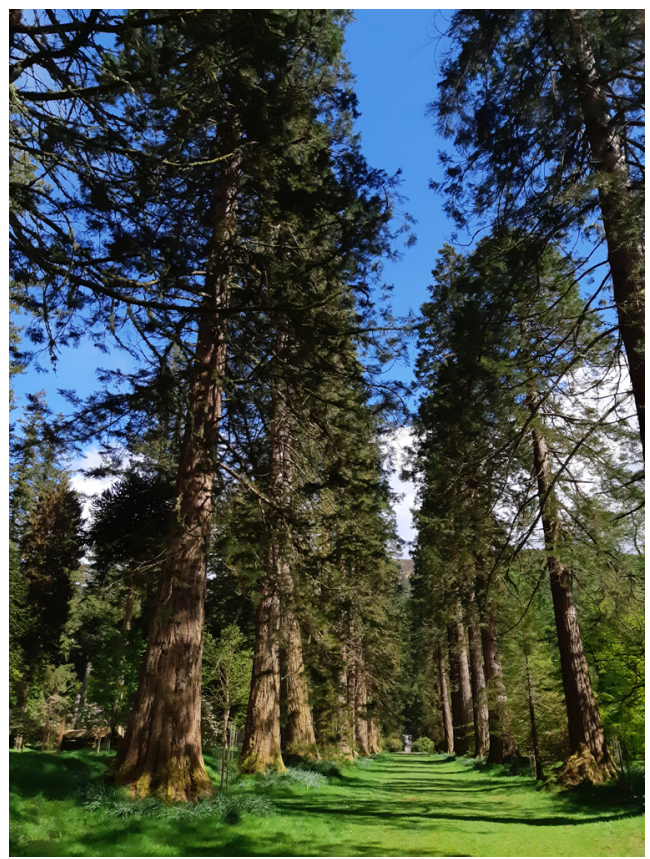

Fig. 4 The Redwood Avenue at Benmore. Photo: David Knott.

\section{Data quality}

Key to any scientific plant collection is the quality and accuracy of the information held within the plant records. Capturing the information on the plants within the Living Collection enhances their value. Data capture of living collections was pioneered at RBGE and can be a useful curatorial tool. The process of data capture includes the verification, photography and creation of voucher specimens of a given group of related plants (Frachon et al., 2009). Carrying out the capture of all this information enables the identification of deficiencies and gaps in the database. In turn, this can inform future fieldwork collections, processes and garden developments. However, it is also vitally important that the plants are checked and the records audited and updated through regular stocktakes. These periodic stocktakes are carried out separately from data capture projects.

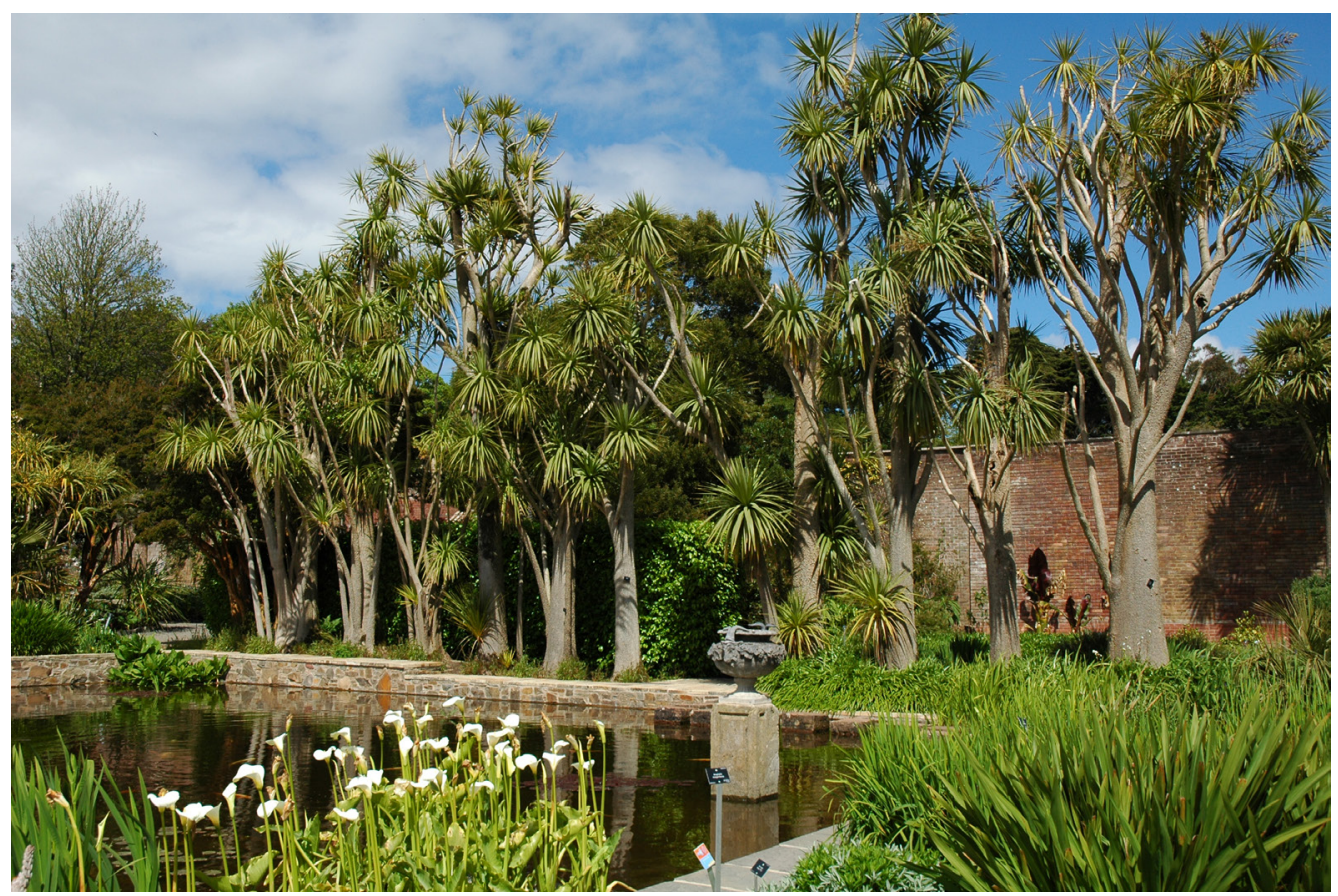

Fig. 5 The Walled Garden at Logan provides additional shelter, enabling the cultivation of Cordyline australis and other species not grown widely in Scotland due to low temperatures. Photo: David Knott. 


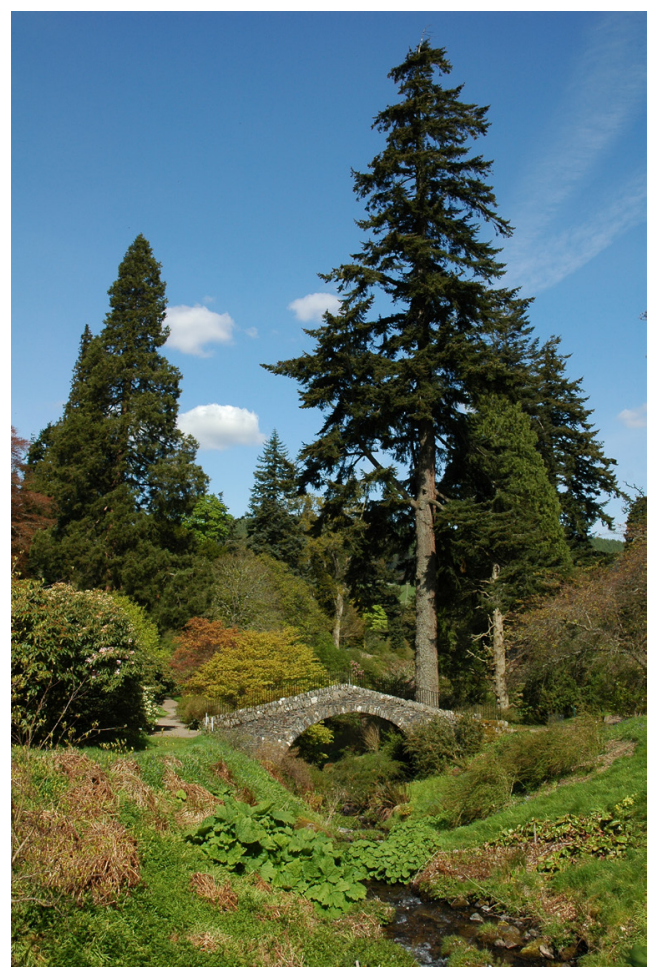

Fig. 6 The Swiss Bridge at Dawyck. Photo: David Knott.

Labelling is an integral element of any scientific plant collection, and for decades all plants in the garden have had a standard black label affixed or displayed close by. In recent years, other label colours have been added. A blue label denotes a Champion Tree, a yellow label indicates that the plant is part of the phenology project (its flowering times are monitored weekly and recorded) and a red label denotes the conservation status of a particular species according to the International Union for Conservation of Nature (IUCN) Red List Threat Classification Scheme (IUCN, 2021) (Figs 7-9). Red labels are only applied to Rhododendron species at the time of writing. This labelling of the rhododendron collection has been undertaken as part of RBGE's role as lead member of the Global Rhododendron Conservation Consortium. The Consortium is conducted in partnership with Botanic Gardens Conservation International (BGCl) and involves collaboration with other institutions worldwide (BGCl, 2018).

All fieldwork is undertaken once a careful audit of the Living Collection has identified gaps or data deficiencies. No plants or seed are collected without full compliance with international guidelines and requirements. RBGE staff work closely with in-country partners. Fieldwork in recent years has taken members of the Horticulture Division to Chile, China, Japan, Nepal, Russia, Tajikistan, Tanzania, the USA and Vietnam.

\section{Geographical displays}

Plant displays across all four gardens are today more naturalistic and ecological in their design than the more formal style which was prevalent many years ago. Planting schemes either reflect geographical areas of the world where RBGE has active research programmes, or where there is or has been a long historical association and cultivation of species from the region. A good example of a planting which reflects an active research programme is the Chilean Hillside at Benmore. This area covers 5 ha of one of the slopes of the garden and has been steadily planted up since 1997 . The plants have been grown from seed and cuttings wild collected from naturally occurring populations in Chile. The 'backbone' of the planting is formed by threatened conifer species from the ICCP, which is based at RBGE (Rae, 2011).

A good example of a naturalistic display is the Japanese Valley at Benmore (Fig. 10). Japan is on the eastern extremity of the Sino-Himalayan floristic region. Its wealth of temperate plants grow well in the Scottish climate and the flora has long been of interest 


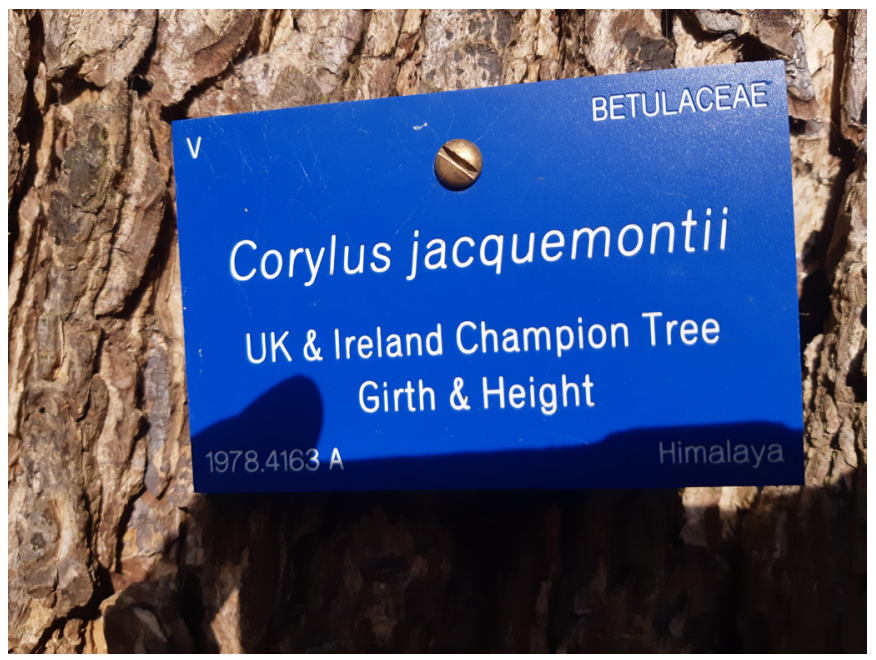

Fig. 7 A blue label denotes a

Champion Tree. Photo: David Knott.

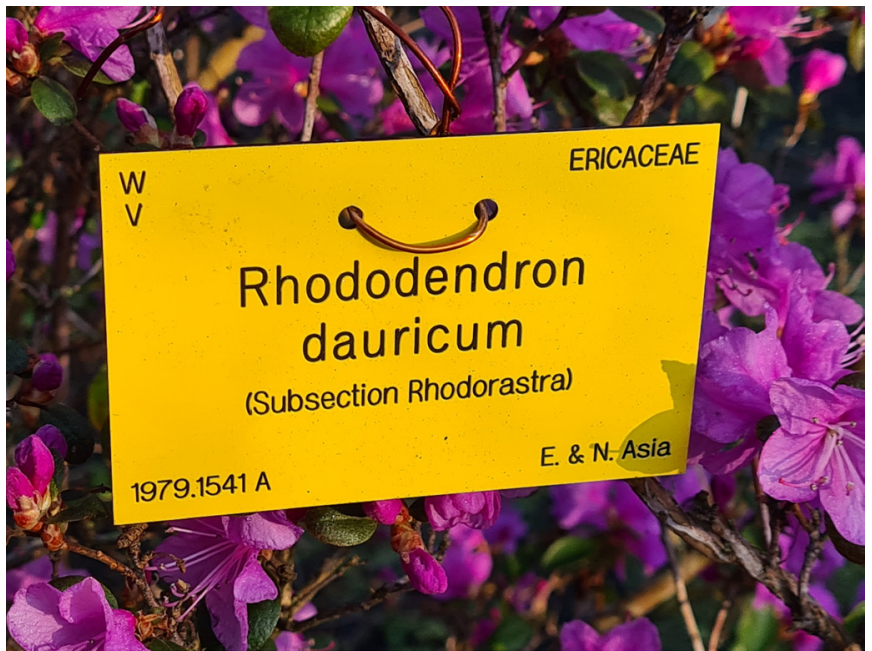

Fig. 8 A yellow label indicates plants whose growth stages are examined regularly for phenology studies. Photo: David Knott.

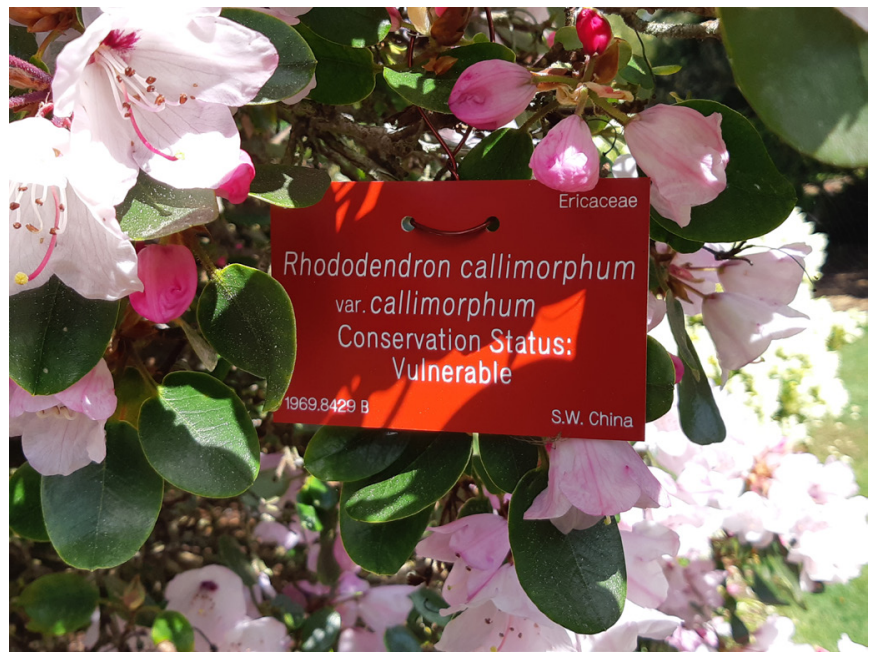

Fig. 9 A red label indicates a plant identified as threatened according to IUCN threat categories. Photo: David Knott. 


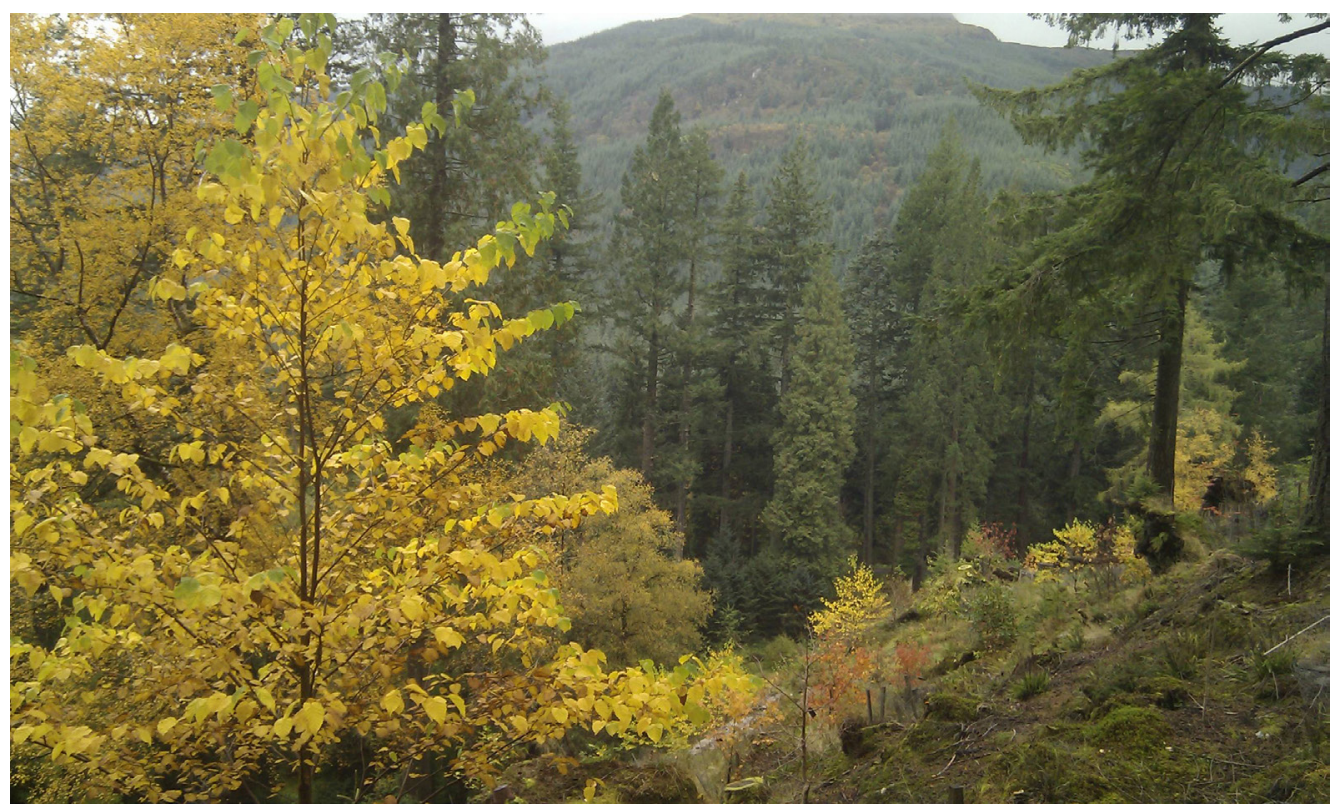

Fig. 10 The Japanese Valley at Benmore with autumn colour of Acer and Betula species in the foreground. Photo: Peter Baxter.

to RBGE. However, following an audit of the information held on Japanese plants in the early 2000s, fieldwork was undertaken to improve the quality of these species in the Collection. This fieldwork resulted in a wealth of new material that is now enhancing displays in each of the four gardens, and can best be seen in the Japanese Valley at Benmore. These displays improve as they mature and, particularly in autumn, make a stunning display and add significantly to the garden landscape.

\section{The glasshouses at the Edinburgh Garden}

At the Edinburgh Garden there is a diverse range of glasshouses of varying ages, from the oldest, the Tropical and Temperate Palmhouses, to the Front Range, constructed in the 1960s. The back-up glasshouses and those holding the research collections were built in the 1970s and 1980s and the most modern glasshouse is in the Nursery, constructed in 2018. There are also two Alpine Houses accessible to visitors, one with displays that change weekly, and one with permanent plantings. The Public Display Glasshouses showcase ten different themes, each of which has a different climatic regime. They are: Temperate Palms; Tropical Palms; Temperate Montane Flora; Tropical Montane Flora; Orchids and Cycads; Ferns; Plants and People; Tropical Plants; Arid Plants; and Non-hardy Temperate Plants. Within these glasshouses 2,549 species are cultivated, with over 51 per cent being wild collected. The glasshouses are the only part of the Edinburgh Garden where admission charges apply. In 2019 there were 118,764 visitors to the glasshouses.

The Research Glasshouses are only accessible to staff. They comprise 17 different glasshouses, including propagation and quarantine facilities, with a variety of sizes and environments. The plant collections express the key research areas of the 
institute and the groups cultivated include plants from the Arabian peninsula, conifers, ferns, Begonia, Ericaceae, Gesneriaceae and Zingiberaceae. Within these Research Glasshouses, 4,285 species are cultivated, with over 74 per cent wild collected. The collections also include seven Plant Heritage collections.

\section{The Outdoor Living Collection}

The Outdoor Living Collection is a rich and diverse plant collection, and in recent years several areas of the garden have been redeveloped. The Lower Woodland Garden is north facing and provides an ideal microclimate for moisture-loving plants. Gentians, primulas and Meconopsis species grow very well here, and these plantings have been revamped and expanded and the area re-landscaped. The Herbaceous Border has been renovated over several years with the magnificent Beech Hedge as a backdrop. New areas have been developed for the first time; these include the Queen Mother's Memorial Garden and the Biodiversity Garden. This is a highly ornamental display which also demonstrates the plant groups in the context of an evolutionary timeline. The Biodiversity Garden provides a picturesque view from the restaurant and decking of the John Hope Gateway, the garden's visitor centre, which was opened to the public in 2010. More recent developments such as the Nepalese and Japanese-themed plantings reflect collaborative work in which RBGE staff are involved.

At the Edinburgh Garden there are 3,268 trees, representing 56 families, 145 genera and 728 species. Approximately 1,900 of the 3,268 trees are of known wild origin, and the collection is being constantly added to with new wild-origin plantings. The value of wild-collected propagules is that the genetic diversity of species can be safeguarded in cultivated collections with careful record management. Genetic diversity is essential for the conservation of a species because to maintain healthy populations the vigour afforded by a mix of genetic backgrounds is essential (see also Gardner, 2021 in this volume). The tree collection reflects the long history of RBGE and also the future interests of the organisation: it provides an invaluable research collection, an educational resource and, especially in 2020 and early 2021, extremely valuable high-quality urban greenspace for local visitors experiencing travel restrictions due to COVID. The trees also provide habitat for a wide range of birds, insects and other wildlife, which is notable for an area so close to an urban environment (Mill, 2012).

\section{Alpine plants}

RBGE has had a long-established interest and expertise in the cultivation of alpine plants since the time that Professor John Hutton Balfour, Regius Keeper 1845-1879, led excursions into the Scottish hills to learn about and collect the plants growing there. To accommodate these plants, James McNab, Curator 1849-1878 and son of William McNab, created the Rock Garden (Fletcher \& Brown, 1970).

A critical comment made by the plantsman and author Reginald Farrer in 1907 that described the Rock Garden, with its small pockets for plants, as 'the Devil's Lapful' (Farrer, 1907) prompted Isaac Bailey Balfour, Regius Keeper 1888-1922, and Robert Harrow, Curator 1902-1931, to dismantle it and create a more naturalistic version. This was the foundation of the Rock Garden that visitors walk through today. The equitable climate in Scotland, being neither too warm nor too cold at any time of year, 
allows alpines to be grown from many of the mountain ranges of the world relatively easily, with the input of skilled horticulture staff and a limited amount of infrastructure.

Many high alpines are normally protected and covered by snow during the winter, and the lack of snow cover at sea level in Edinburgh, coupled with what is called 'dreich' winter wet in Scotland, means that those plants that in their natural habitats would be covered with snow have to be protected from the rain by a pane of glass. Potted alpine plants are displayed differently. Unheated covered frames and glasshouses are used to grow plants in pots. The traditional Alpine House is a wooden-framed glasshouse with sand benches at eye level used to display plants to visitors. Plants are placed on the sand benches when in flower and the display is rotated on a weekly basis with plants from the 'behind the scenes' collections.
These displays include cushion plants such as Dionysia species, early flowering Primula allioni and a wide variety of bulbs. In 2012 an unheated Alpine House that relies on natural ventilation for air movement was constructed. This new Alpine House enables alpine plants to be on permanent display in a more naturalistic setting (Fig. 11). Dionysia species and Paraquilegia anemonoides are planted into a specially created vertical tufa wall that provides free-draining conditions similar to their native habitats. The open sides of the structure provide natural air movement which plants adapted to high altitudes require to thrive.

\section{Scottish native plants}

The skills and knowledge gained by the horticulture team through cultivating difficult alpine plants have been transferred to programmes that reintroduce species to

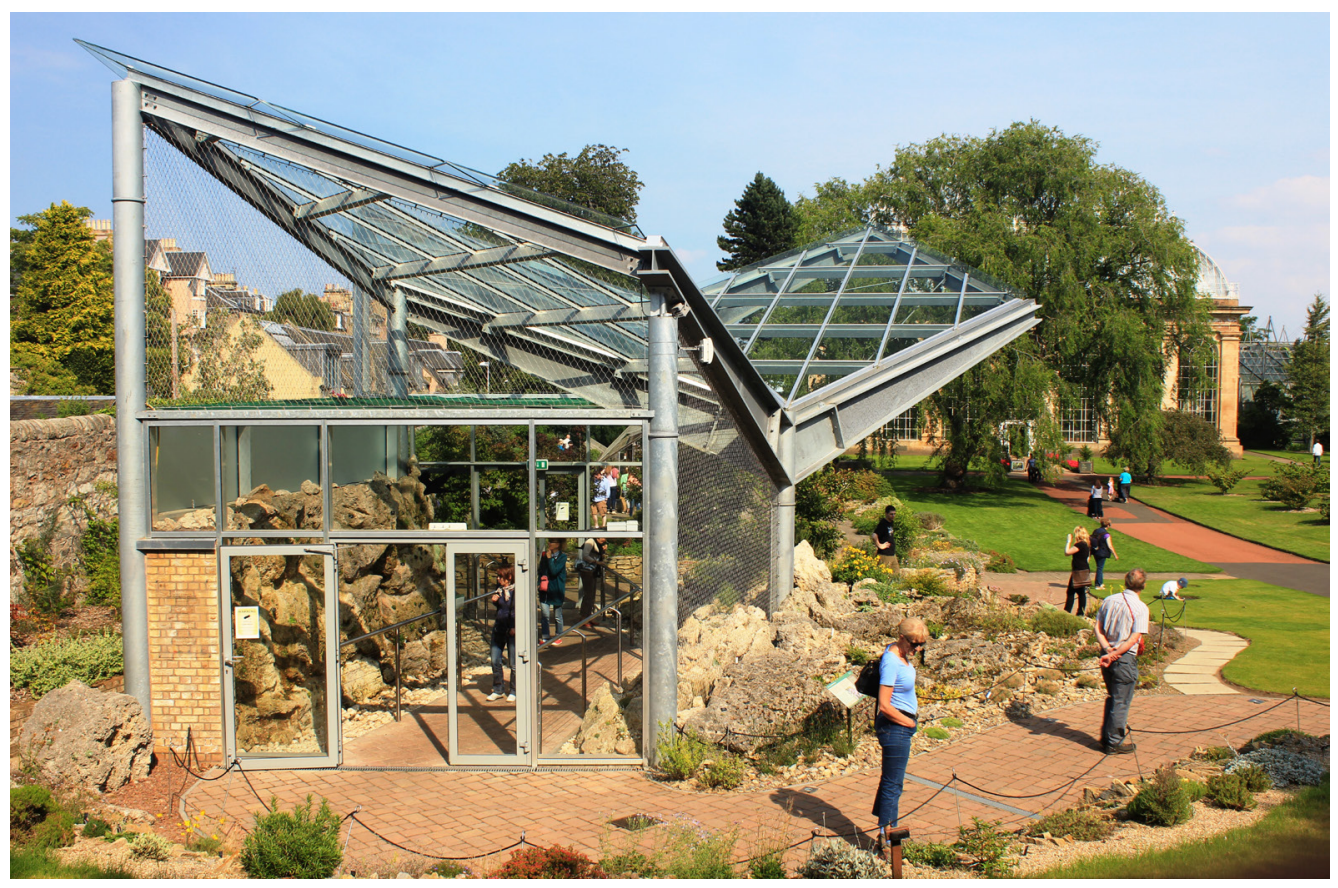

Fig. 11 The new Alpine House has a clear but solid roof and is open on all sides to allow ventilation while protecting plants from rainfall. Photo: David Knott. 
native habitats in Scotland. Restoration work has been undertaken on nine threatened plant species, including the montane willows Salix lanata, S. lapponum and S. myrsinifolium in the southern Cairngorms (Fig. 12). Such projects draw together the skills of the science and horticulture staff, and good results are achieved by working in partnership with other organisations such as the conservation organisation Nature Scotland (formerly Scottish Natural Heritage) (Barnard, 2014).

Not everyone will have the opportunity to see and marvel at these plants in their natural habitats, and raising awareness of the pressures that Scottish native plants

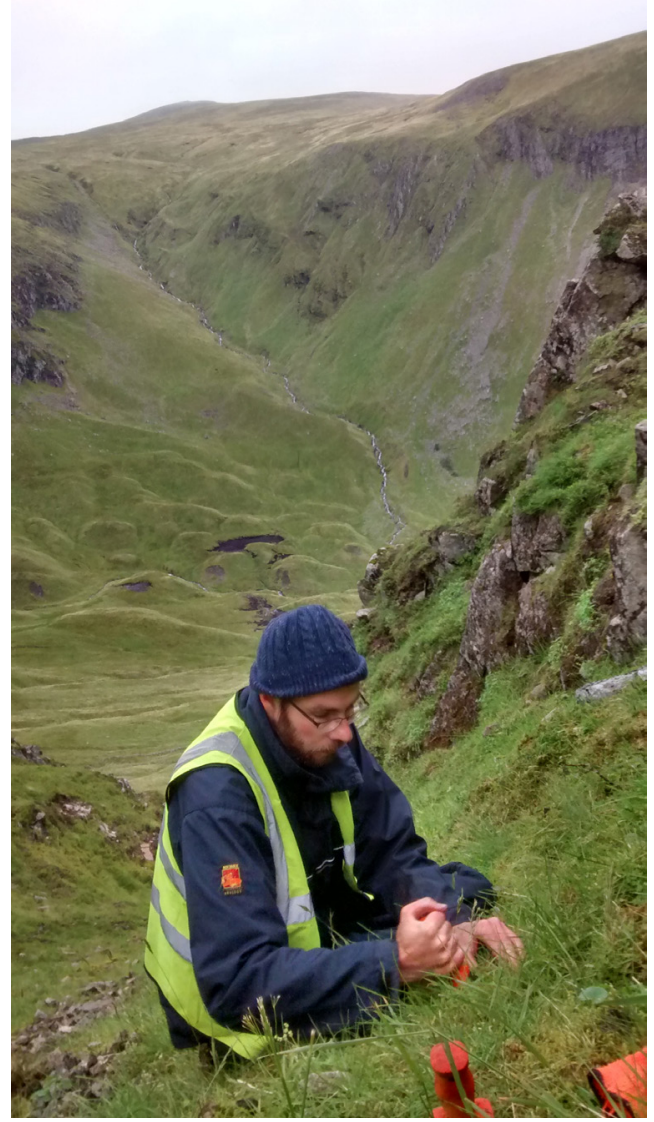

Fig. 12 An RBGE horticulturist planting montane willows in Cairngorms National Park in the Scottish Highlands. Photo: Natacha Frachon. face through plantings and associated interpretation at both the Edinburgh and Dawyck Gardens creates links with our work in Scotland for visitors. Raising the profile of native plants is also possible through long-term changes in landscape management such as the grass-cutting regimes at Dawyck. Mowing the grass less frequently in the growing season has resulted in increasing numbers of individuals of the native orchid Dactylorhiza fuchsii in the grassland.

Some areas of the garden have been cultivated to demonstrate that the biodiversity and attractiveness of a lawn and garden can increase significantly by changing the height and frequency of grass cutting. Aptly named 'Living Lawns' have been created and signposted (Fig. 13). In other areas, annual seed mixes have been sown, such as a Cornfield annual mix and, in 2020, a Pictorial Meadow mix, containing a range of brightly coloured annual flowering plants. All of these seasonal displays enhance biodiversity, and they are interpreted to the visitor with information boards in order to raise awareness of their benefits.

\section{Titan arum flowering event}

Novel events that present the garden or buildings in a different light always attract new visitors, sometimes with the added benefit of increased income generation. The first flowering in Scotland of the iconic plant Amorphophallus titanum (titan arum) in 2015 was just such an event and drew 19,000 visitors to stand in queues for up to two hours in order to catch sight of the extraordinarily huge inflorescence (Fig. 14). The plant was nicknamed 'New Reekie' and really captured the public's imagination, in part helped by having its own Twitter account. The name derived from 'Auld Reekie', the old nickname 


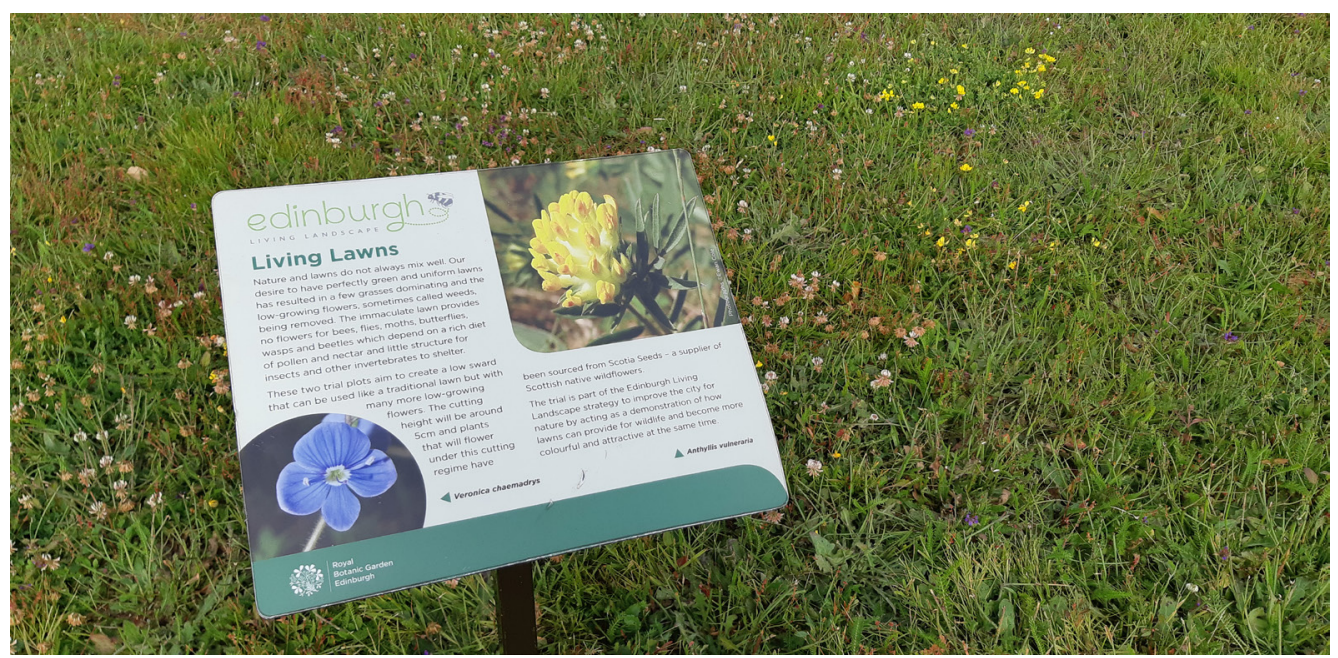

Fig. 13 'Living Lawns' have been cultivated in lawn areas of the Edinburgh Garden and have interpretation boards so that visitors know why these sections of lawn look different from the rest. Photo: David Knott.

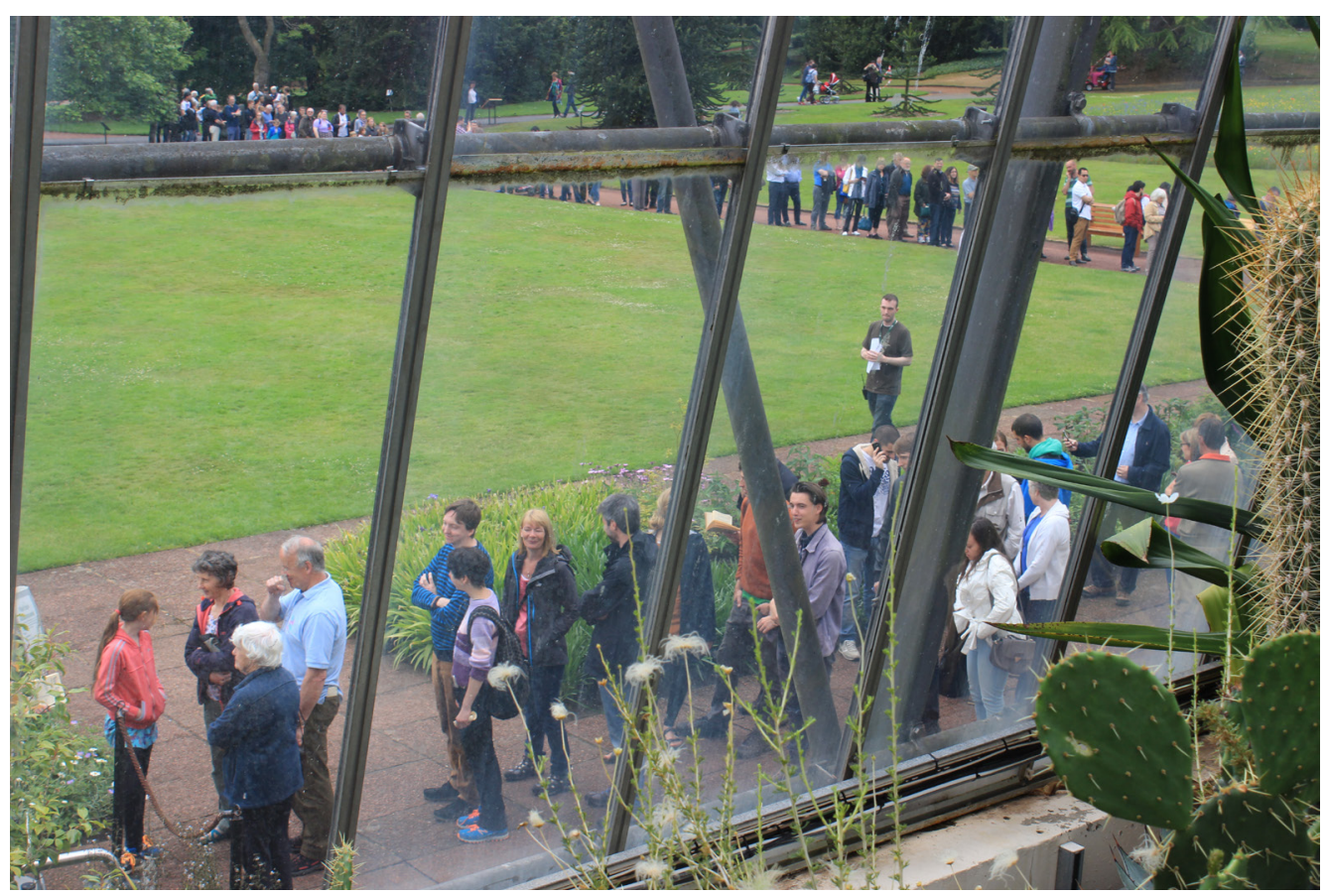

Fig. 14 Visitors waited for two hours in queues outside the Glasshouses to take their turn to see the huge inflorescence of titan arum in the Tropical Lowlands House. Photo: David Knott.

for Edinburgh, from the strong-smelling smoke from chimney fires that used to hang over the city. In anticipation of the strongsmelling flower of titan arum, and as a new accession to the collection, 'New Reekie' seemed like a fitting name. Staff from all departments across the organisation worked hard in a fantastic team effort to make this event an enjoyable but thoroughly tiring five days! 


\section{The changing climate}

Changes in the climate and weather patterns over the last twenty years have created a number of challenges in the cultivation of the Living Collections across all four gardens. These impacts have included drier springs, above average summer temperatures, higher autumn and winter rainfall levels, more intense rainfall events throughout the year, severe wind and extreme cold. All of these factors affect both plant growth and physical access to the plants in order to care for them. The only impact of climate change which has not been experienced is a significant increase in temperatures (heat). Some of these impacts have been partially mitigated through the use of mulches to conserve water, the installation of more effective drainage to reduce problems associated with a fluctuating water table, and the installation of irrigation and rainwater harvesting.

The average rainfall in Edinburgh has been increasing steadily over the last 50 years (Met Office, 2021). The rainfall pattern has also changed; longer drier spells interspersed with rainfall of greater intensity has led to increased risk of flooding. One solution to this problem of increasing rainfall in urban areas is the use of raingardens. They mimic natural rainwater retention and through soil amelioration measures and careful plant selection can have the added benefit of enhancing biodiversity. Kelly et al. (2020) describe how a raingarden was made at RBGE in partnership with researchers at Heriot-Watt University. An area that suffered regularly from flooding was selected and the hydrology of that area studied. Then the soil was ameliorated in the area to enhance infiltration of rainwater with the addition of sand and gravel to specific sizes and proportions. Once this material, which increased the drainage capacity of the area, had been incorporated the area was planted up. The raingarden now functions as a living laboratory, and its effectiveness and plant behaviour are monitored. The plantings will be adapted as required.

A key priority for the future is effective planning to have the right plant in the right garden and location within each garden in anticipation of what the future climate will be. In February 2021 RBGE joined the Climate Change Alliance for Botanic Gardens. This self-organising global group of botanic gardens and arboreta has access to peer support and a modelling tool developed by the University of Tasmania in collaboration with the Royal Botanic Gardens Victoria, Melbourne (both in Australia) and data held in $\mathrm{BGCl}$ databases. The tool brings together climate data and plant species, and will be useful for curation and planning in a changing climate. It enables horticulturists to ascertain the suitability of a species to the projected climate for their particular garden (see Symes \& Hart, 2021 in this volume). RBGE is fortunate to have four gardens with quite different climatic conditions within $150 \mathrm{~km}$ of each other. This range of locations means there are opportunities to move plants around from one garden to another to get the best possible conditions for growth if they are not doing well in their current position. These possibilities could continue to be an asset as conditions change with increasing pace.

\section{Plant health}

These subtle changes in climate and the increasing globalisation in plant movement have also contributed to significant plant health issues in gardens worldwide. At RBGE there have been problems with Phytopthora 
ramorum and $P$. austrocedri. For example, a mature specimen, over 100 years of age, of a Rhododendron cultivar had to be removed from the Lower Woodland Garden when it was found to be infected with $P$. ramorum. Chalara fraxinea (ash dieback) is beginning to have an impact on the Fraxinus collection because infected plants have to be removed, and Cameraria ohridella (horse chestnut leaf miner) appeared in Edinburgh in 2017. Staff are anxious but vigilant in the hope that Thaumetopoea processionea (oak processionary moth), Agrilus planipennis (emerald ash borer) and Anoplophora chinensis (citrus longhorn beetle), and the bacterium Xylella fastidiosa (xylella), will not appear in Scotland. These pests and diseases cause serious problems for plants, and in the case of oak processionary moth, human health. The dissemination of information to staff, and horizon scanning through communication with other organisations are important actions to mitigate against the potential impacts of such diseases. Networks such as the International Plant Sentinel Network (Barham et al., 2015; Marfleet \& Sharrock, 2020) are important in facilitating the communication required between landscape managers.

\section{Invasive non-native species}

Subtle changes in climate and lack of timely removal have led to a number of plants becoming invasive non-native species across the globe. In Scotland, Heracleum mantegazzianum (giant hogweed), Fallopia japonica (Japanese knotweed), Impatiens glandulifera (Himalayan balsam) and Rhododendron ponticum all shade out native species, particularly along fragile stream and riverside habitats. R. ponticum creates dense shade in woodland habitats and provides a host for diseases such as Phytopthora species (described above). These species are garden escapees which have become part of increasingly expensive eradication programmes in the four RBGE gardens. Lysichiton americanum (skunk cabbage) covering large areas of Dawyck has been removed, and there is an active programme to remove $R$. ponticum at Benmore. One plant under close scrutiny is Gunnera tinctoria. It has become a problem in south-west England, western Ireland and the Western Isles of Scotland. Monitoring plants for their invasiveness before they become a problem is extremely important.

\section{Environmental sustainability}

The Horticulture Division has been at the forefront of RBGE's drive to improve its environmental sustainability. Innovative projects have included the installation of air-source heat pumps to heat the conservatory at Logan in 2014, and the installation of a biomass boiler and micro hydro scheme at Dawyck in 2012. These two features plus the establishment of a sedum roof on a well-insulated building constructed to stringent environmental standards (Fig. 15) lead the author to believe that Dawyck is the first carbon-neutral botanic garden in the world. Staff have introduced other everyday initiatives, such as extensive waste recycling and energy savings, which earned Dawyck a Gold Award for Green Tourism Environmental Management and led to a significant reduction in the energy impacts of running the garden. The Logan and Edinburgh Gardens have also maintained Gold Awards since 2016.

At the Edinburgh Garden, other initiatives have been implemented to reduce the carbon impact of horticultural activities. The use of peat in compost mixes has been significantly reduced, with peat now replaced 


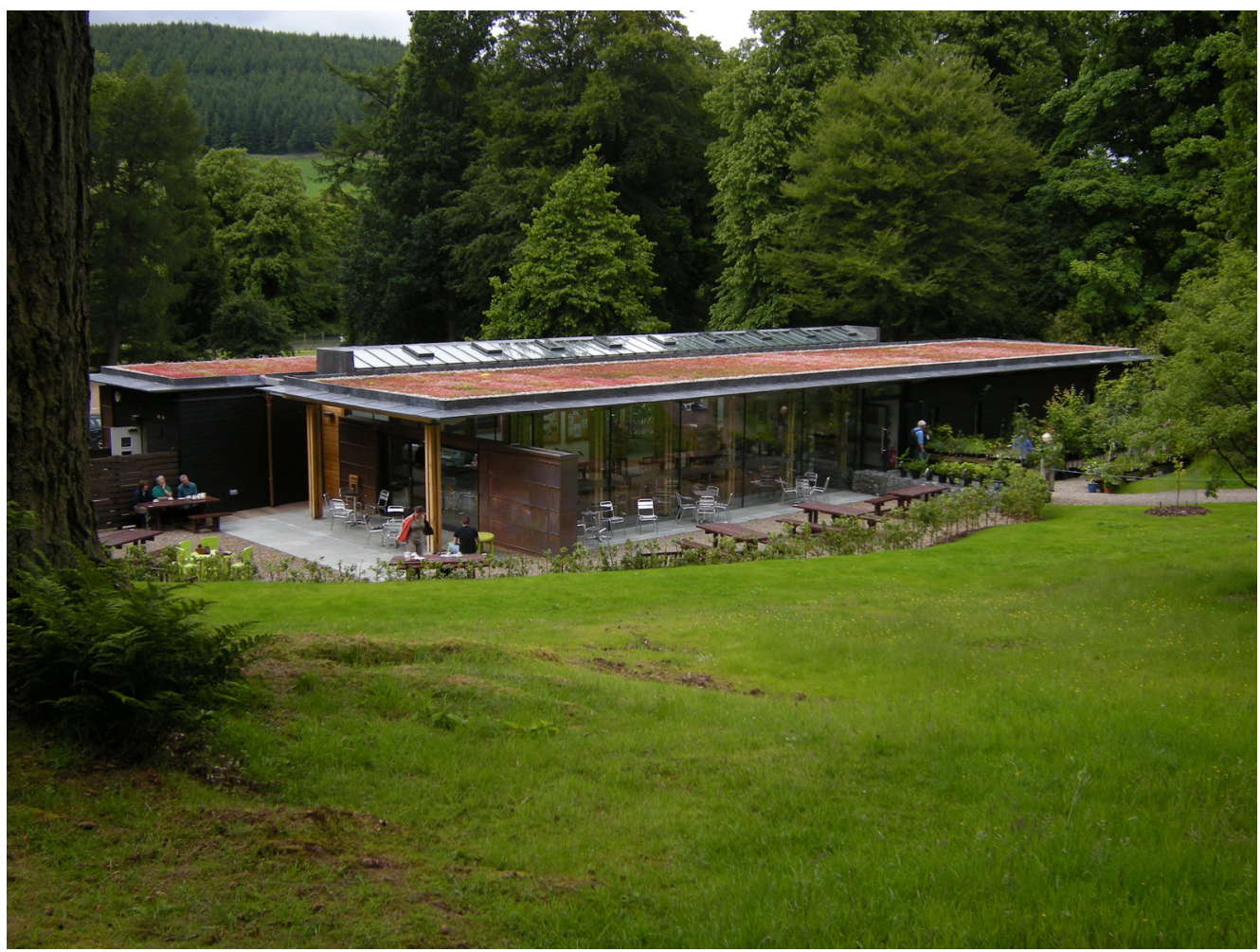

Fig. 15 The Visitor Centre at Dawyck with its sedum roof. Photo: David Knott.

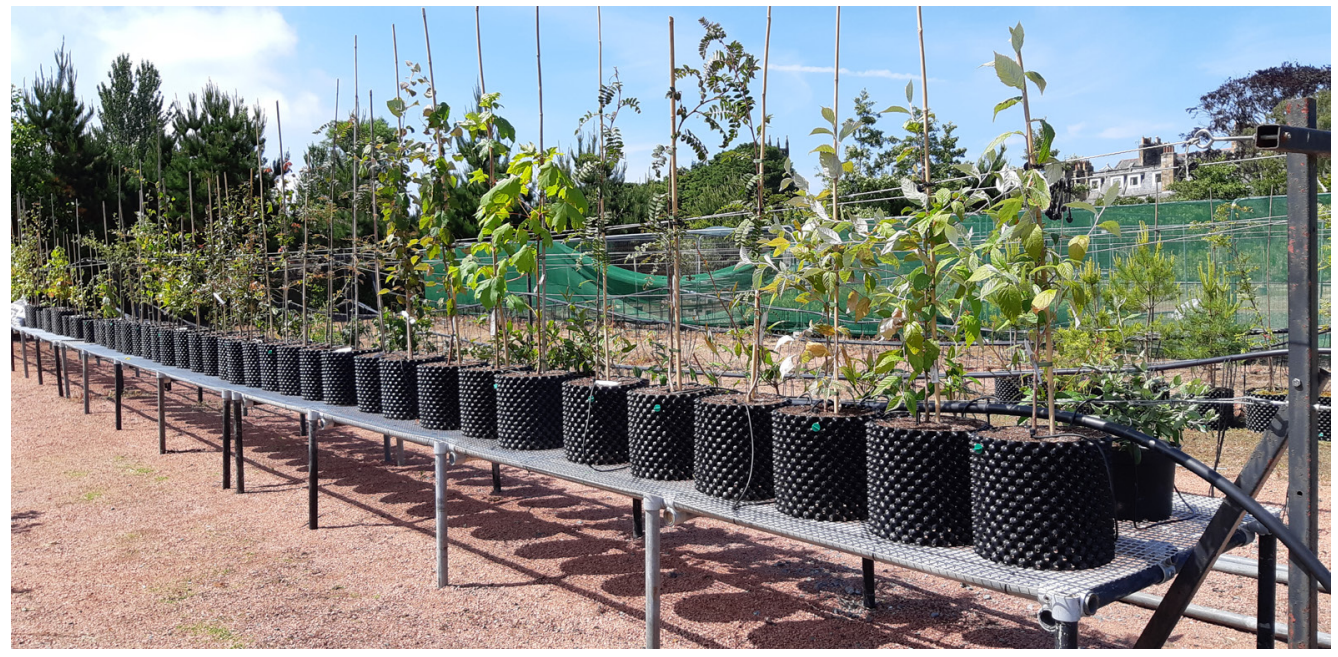

Fig. 16 Most tree species are grown on in Air-Pots ${ }^{\circledR}$ in the RBGE Nursery. Photo: David Knott.

with bark where possible. Trees and shrubs are now grown on in Air-Pots ${ }^{\circledR}$ (Fig. 16) made from 95 per cent recycled plastic. We have begun the shift towards using electric hand tools where the task and resources allow. The robotic lawnmower has now travelled $13,335 \mathrm{~km}$, with much less noise and lower energy consumption than the equivalent 
petrol-driven lawnmower. In the glasshouses, the use of chemicals has been dramatically reduced, replaced with biological controls (Ives, 2020).

\section{The Botanic Cottage}

Today the Botanic Cottage is at the heart of an extremely vibrant part of the Edinburgh Garden. This building was once the home of Principal Gardener John Williamson and the classroom of John Hope at the garden's previous site on Leith Walk in the 1760s. The building, which was in a poor condition but still on its original site, was moved stone by stone when a staff member found that it was marked for demolition (Forsyth, 2016). It is now the base for many community and volunteering activities including the Edible Gardening Project, funded by the
People's Postcode Lottery (Foulkes, 2017), the Schools Gardening Programme and the students' plots which are an important part of a module in the HND in Horticulture with Plantsmanship course, delivered in association with Scotland's Rural College (Fig. 17).

\section{The future}

Perhaps the single greatest impact on the Living Collection in recent years occurred on 3 January 2012, when winds reaching $160 \mathrm{kmh}$ caused extensive damage to the Living Collection across all four gardens and particularly to the Research Glasshouses at the Edinburgh Garden. In July 2020 the Scottish Government granted $£ 50$ million to RBGE to address the problems afflicting the ageing buildings and glasshouses.

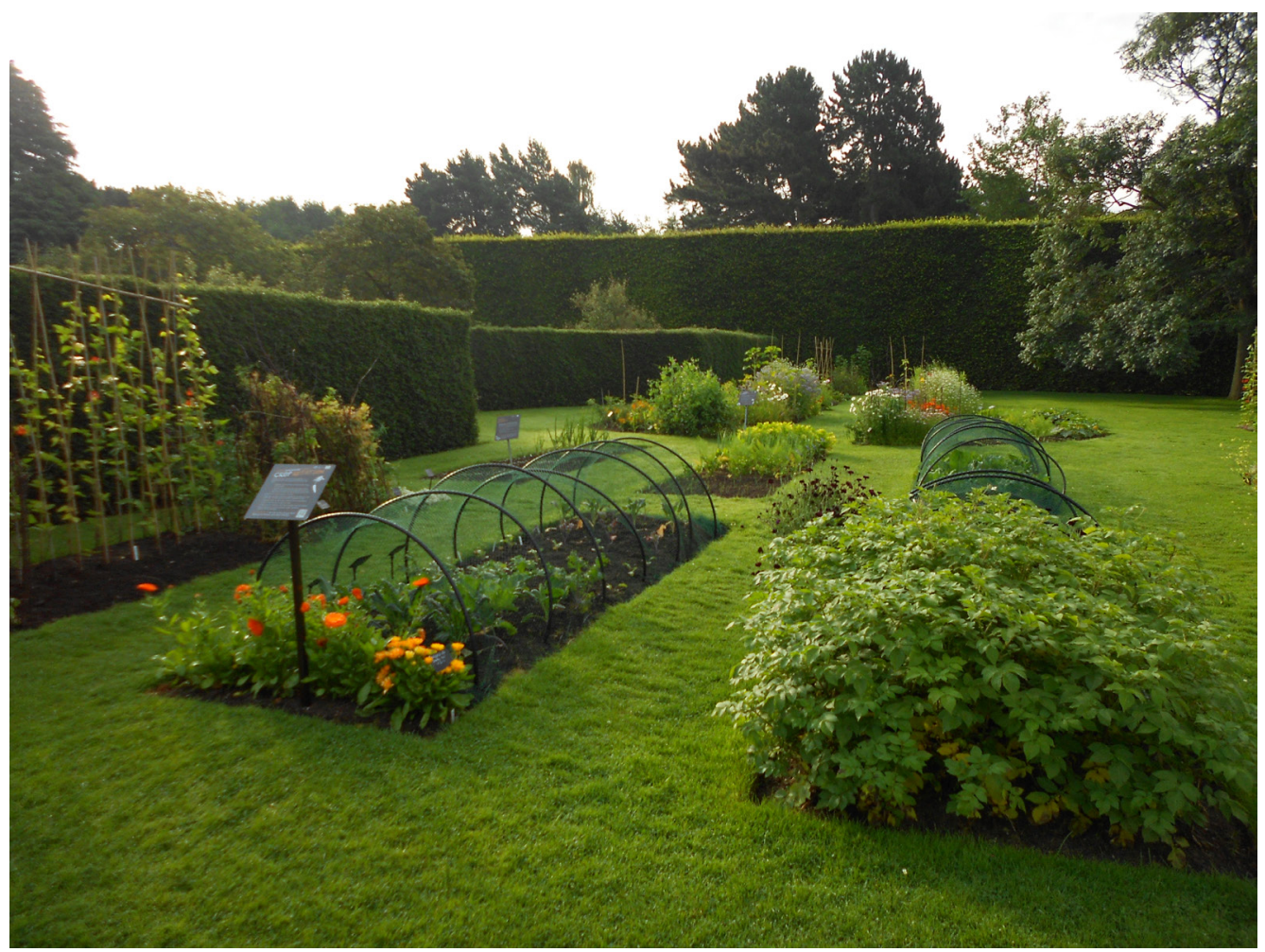

Fig. 17 The Edible Gardening Project demonstrates good growing practice and hosts groups from the local community who cultivate vegetables and flowers in their own plots. Photo: RBGE. 
Exciting plans are underway at the time of writing (2021) to embark on a complete transformation of the Research and Public Display Glasshouses. The project includes plans to construct a new Plant Health suite and a multi-level display glasshouse in a prominent position adjacent to the Herbarium, along with an energy-efficient heat source.

\section{Conclusion}

Throughout 2020, in particular, the value and importance of plants and gardens were highlighted because people did not have many of the distractions and the freedom to travel that they were accustomed to. Each of the gardens is an attractive place to relax, walk and enjoy events, as well as to learn about the importance of plants. As well as many of these plants providing an amenity and educational resource in each of the four gardens, they are also an increasingly important conservation and scientific resource for RBGE and plant scientists around the world. The Collection Policy states the priority for wild-origin material, and many new collections are grown from seed collected by RBGE staff and collaborators undertaking joint fieldwork.

However, visitors to the gardens require facilities, and in the last 15 years new entrance buildings to welcome visitors to both the Edinburgh and Dawyck Gardens have been constructed, with more facilities across all four gardens planned to improve the visitor experience.

The many different plant species cultivated across all four fine garden landscapes and glasshouses that make the Living Collection what it is today would not be possible without the skill, dedication and hard work of the horticultural team over the last 350 years (Fig. 18).

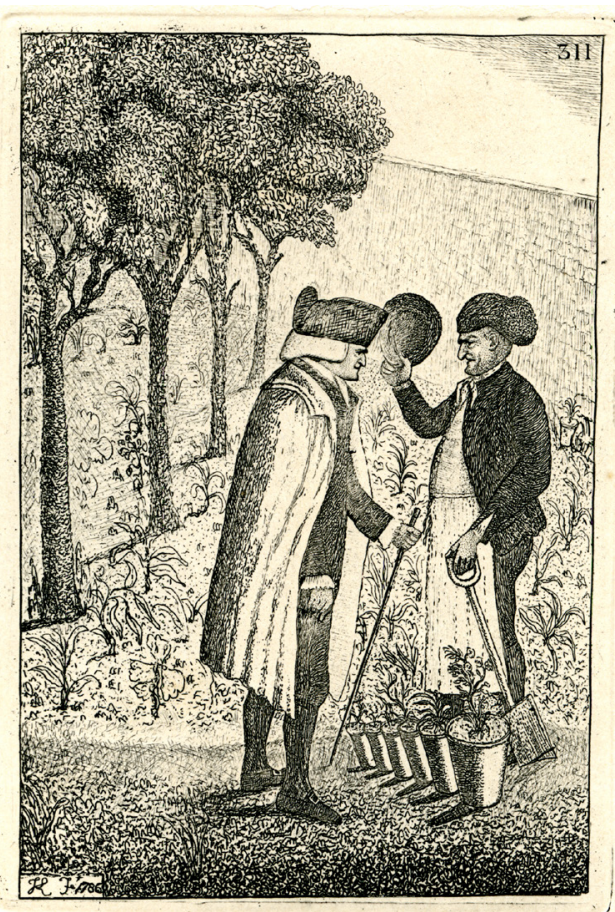

Fig. 18 John Hope talking with the Principal Gardener, presumed to be Malcolm McCoig, at the Leith Walk garden, 1786. Engraving by John Kay, reproduced with the permission of RBGE Library and Archives.

\section{References}

ANTONELLI, A., FRY, C., SMITH, R.J., SIMMONDS, M.S.J., KERSEY, P.J., PRITCHARD, H.W. ET AL. (2020). State of the World's Plants and Fungi 2020. doi: https://doi.org/10.34885/172

BARHAM, E., SHARROCK, S., LANE, C., \& BAKER, R. (2015). An International Plant Sentinel Network. Sibbaldia, 13: 83-98. doi: https://doi.org/10.24823/ Sibbaldia.2015.75

BARNARD, K. (2014). Monitoring populations of Saxifraga cespitosa in Scotland. Sibbaldia, 12: 99-110. doi: https://doi.org/10.24823/ Sibbaldia.2014.26

\section{BOTANIC GARDENS CONSERVATION} INTERNATIONAL (2018). Global Conservation Consortium for Rhododendron. Available online: https://www.bgci.org/our-work/plantconservation/global-conservation-consortia/ global-conservation-consortium-forrhododendron/ (accessed February 2021). 
FARRER, R. (1907). My Rock Garden. Arnold, London.

FLETCHER, H.R. \& BROWN, W.H. (1970). The Royal Botanic Garden Edinburgh 1670-1970. HMSO, Edinburgh.

FORSYTH, S. (2016). Discover the Botanic Cottage. RBGE, Edinburgh.

FOULKES, J. (2017). The value of community engagement in botanic gardens with examples from the Royal Botanic Garden Edinburgh. Sibbaldia, 15: 121-128. doi: https://doi. org/10.24823/Sibbaldia.2017.227

FRACHON, N., GARDNER, M. \& RAE, D. (2009). Data Capture Project at the Royal Botanic Garden Edinburgh. Sibbaldia, 7: 77-82. doi: https://doi. org/10.24823/Sibbaldia.2009.152

GARDNER, M. (2021). Managing botanic garden collections of high conservation value. Sibbaldia, 20: 81-94. doi: https://doi.org/10.24823/ Sibbaldia.2021.360

\section{INTERNATIONAL UNION FOR CONSERVATION OF} NATURE (2021). The IUCN Red List of Threatened Species. Version 2020-3. Available online: https:// www.iucnredlist.org/resources/threat-classificationscheme (accessed February 2021).

IRISBG (2017). IrisBG Botanical Garden Collection Management (Version: 3.6.4.17114 - date: 2017-1127). Data management software. Available online: https://www.irisbg.com/ (accessed May 2021).

IVES, J. (2020). Biological controls in botanic gardens. Sibbaldia, 18: 117-125. doi: https://doi. org/10.24823/Sibbaldia.2020.292

KELLY, D., WILSON, K., KALAICHELVAM, A. \& KNOTT, D. (2020). Hydrological and planting design of an experimental raingarden at the Royal Botanic Garden Edinburgh. Sibbaldia, 19: 69-84. doi: https://doi.org/10.24823/Sibbaldia.2020.298
MARFLEET, K. \& SHARROCK, S. (2020). The International Plant Sentinel Network: an update on phase 2. Sibbaldia, 18: 105-116. doi: https://doi. org/10.24823/Sibbaldia.2020.291

MET OFFICE (2021). Historic station data for Leuchars. Available online: https://www.metoffice. gov.uk/research/climate/maps-and-data/historicstation-data (accessed May 2021).

MILL, R. (2012). Biodiversity recording at Royal Botanic Garden Edinburgh. Sibbaldia, 10: 149-170. doi: https://doi.org/10.24823/Sibbaldia.2012.84

NOLTIE, H.J. (2011). John Hope (1725-1786): Alan G. Morton's Memoir of a Scottish Botanist. RBGE, Edinburgh.

RAE, D. (2011). The Living Collection. RBGE, Edinburgh.

RAE, D., BAXTER, P., KNOTT, D., MITCHELL, D., PATERSON, D. \& UNWIN, B. (2006). Collection Policy for the Living Collection. RBGE, Edinburgh.

SUTHERLAND, J. (1683). Hortus medicus Edinburgensis, or, A catalogue of the plants in the Physical Garden at Edinburgh : containing their most proper Latin and English names; with an English alphabetical index. Printed by heir of Andrew Anderson, Edinburgh. Available online: www.biodiversitylibrary.org/bibliography/60620 (accessed February 2021).

SYMES, P. \& HART, C. (2021). The Climate Change Alliance: botanic garden horticulturists as agents for change. Sibbaldia, 20: 95-122. doi: https://doi. org/10.24823/Sibbaldia.2021.352

TREE REGISTER (2021). The Tree Register. Available online: https://www.treeregister.org/ (accessed March 2021). 